\title{
Anthropogenic land-use change in the North American tall grass-short grass transition and modification of near-surface hydrologic cycle
}

\author{
Rezaul Mahmood ${ }^{1, *}$, Kenneth G. Hubbard ${ }^{2}$ \\ ${ }^{1}$ Department of Geography and Geology and Kentucky Climate Center, Western Kentucky University, 1 Big Red Way, \\ Bowling Green, Kentucky 42101-3576, USA \\ ${ }^{2}$ High Plains Regional Climate Center, 244, L. W. Chase Hall, School of Natural Resource Sciences, \\ University of Nebraska-Lincoln, Lincoln, Nebraska 68583-0728, USA
}

\begin{abstract}
During the 19th and 20th centuries, the landscape of the North American Great Plains was rapidly modified from natural grasslands to agricultural farmlands. These changes affected much of the continent with potential impacts in grasslands equal to deforestation elsewhere. Therefore, the resulting impacts on weather and climate should be studied. In this study, a soil water balance model is applied for 3 land uses at 3 locations. These locations are representative of the east to west declining precipitation gradient of the Great Plains. It was found, in McCook, Nebraska, for example, that annual total evapotranspiration for irrigated maize is $36 \%$ higher compared to natural grass. This accounts for an additional 50 million $\mathrm{m}^{3}$ of water evapotranspired into the atmosphere from an area of 19000 ha during the growing season. In some instances, Clay Center, Nebraska, and the vicinity evapotranspired nearly 100 million $\mathrm{m}^{3}$ additional water (compared to a grass covered surface) from irrigated maize during the growing season. Compared to grass, irrigated maize farming elevated soil water in the soil profile, while rainfed maize lowered soil water. This study shows that intensity of the response of soil water distribution in the root zone is a function of vegetation cover and soil physical properties.
\end{abstract}

KEY WORDS: Soil moisture · Evapotranspiration · Modeling $\cdot$ The Great Plains · Land-use change

\section{INTRODUCTION}

Human economic activities and associated modifications of land use are contributing significantly to global environmental change (Houghton et al. 1999, Schimel 1999). Land-use changes are also affecting nearsurface hydrologic conditions. Some of the most rapid changes in land use/land cover can be found in the North American Great Plains. During the 19th and early 20th centuries, in Nebraska, like other states of this region, the grasslands were virtually completely turned into agricultural farmlands (Williams \& Mur-

*E-mail: rezaul.mahmood@wku.edu field 1977, Ramankutty \& Foley 1999). Some of the most significant changes occurred during the 1950s and subsequent years with the introduction of irrigation and its rapid adoption and expansion. Over the last 2 decades, much of the research on landscape/climate interactions has focused on deforestation and its impacts on the environment, including the hydrologic cycle (Shukla et al. 1990, Zhang \& Henderson-Sellers 1996, Zeng et al. 1996). However, the extensive transformation of grasslands in the North American Great Plains into cultivated croplands may contribute to changes of near-surface hydrologic cycle components in a similar way. Therefore, it is important that we determine the potential impacts of large-scale landuse change on the land-surface hydrology. 
The objective of the present research was to investigate the potential impacts of the expansion of irrigated agriculture on the near-surface hydrologic cycle components, namely, evapotranspiration (ET) and soil moisture (SM). The state of Nebraska, USA, is selected for this study. Nebraska exemplifies the rapid changes in the land-use/land-cover conditions from grassland and dryland farming to irrigated agriculture in the Great Plains. A descending precipitation gradient from the east to west in Nebraska provides an additional opportunity to determine the response of near-surface hydrologic conditions in naturally sub-humid to semiarid areas to increased irrigation. An operational SM and energy-balance model, developed by Robinson \& Hubbard (1990) (R\&H hereafter) is applied to demonstrate the impacts of land-use changes on ET and SM since 1950. This model calculates SM content for the top 5 layers up to a depth of $1.2 \mathrm{~m}$. SM and land use significantly affect weather and climate at various spatio-temporal scales (Segal et al. 1988, Yan \& Anthes 1988, Pielke \& Zeng 1989, Segal et al. 1989, Wetzel 1989, Milly \& Dunne 1994, Stohlgren et al. 1998, Pielke et al. 1999). This study will improve our understanding of land-use/land-cover changes in the Great Plains and their potential impacts on the near-surface hydrologic conditions and weather and climate of the region.

Pielke et al. (1999) found that land-use change modified time-averaged surface sensible and latent heat flux in South Florida. They also noted changes in local temperature and precipitation due to land-use change. Stohlgren et al. (1998) suggested that modification of adjacent landscape in the Colorado plains is influencing regional climate and vegetation in areas of the Rocky Mountains. They concluded this from a modeling study and by examining independent temperature, stream flow, and vegetation records. Chase et al. (1999) and Segal et al. (1988, 1989) also showed changes in mesoscale atmospheric circulation due to land-use modifications.

Recently, Bonan $(1997,1999)$ attributed changes in temperature and near-surface atmospheric moisture to modification of land use in the United States. Hoffman \& Jackson (2000) reported that conversion of tropical savanna to grasslands has modified precipitation amounts in Africa. Fitzjarrald et al. (2001) and Bounoua et al. (2000) found a relationship between vegetation and vegetative health and near-surface temperature at large scales. Temperature records from various parts of the United States also indicate that modification of the landscape influenced near-surface thermal climate (Balling 1988, Balling et al. 1998, Bonan 2001).

Land-use changes not only modify mesoscale circulation and near-surface atmospheric variables, but also SM storage at the root zone (Chase et al. 1999). The present study investigates the SM aspect of the hydrologic cycle. In addition, ET under the modified land use is also calculated. It is important to improve our knowledge of SM conditions under modified landscape because it affects vegetation health and thus transpiration and radiative properties. This, in turn, affects the energy balance (Mahmood et al. 2001). Moreover, SM in the root zone influences runoff and hence affects the water balance. This study calculates the SM and ET climatology for a much longer time period compared to any of the above studies (e.g. Chase et al. 1999). In addition, these climatologies are prepared for 3 dominant vegetation covers for each of 3 hydrologic regimes. This brings us to an understanding of SM and ET variations related to these land uses.

\section{LAND-USE CHANGE AND R\&H MODEL}

Data from the National Agricultural Statistics Services (NASS) of the United States Department of Agriculture (USDA) are used in this study (www.usda.gov/ nass/). This source provides county annual data on total area (ha) under irrigated and rainfed maize farming since 1950 for Nebraska. Maize is the most dominant agricultural crop in Nebraska (Williams \& Murfield 1977, Sitzman 1996). The data demonstrate that irrigated maize represented about $10 \%$ of total maize producing areas during the early 1950s in Nebraska. Currently, nearly $60 \%$ of all maize-producing areas in Nebraska are under irrigation (Fig. 1).

The framework for the R\&H SM model, which is applied in this study, can be expressed as follows:

$$
\partial S / \partial t=P+I-E T-R_{0}-D_{\mathrm{r}}
$$

where $S(\mathrm{~mm})$ is $\mathrm{SM}$ in the root zone and $t$ is time. The solution is obtained on a $24 \mathrm{~h}$ time step, where $P(\mathrm{~mm})$ is precipitation, $I(\mathrm{~mm})$ is irrigation, $E T(\mathrm{~mm})$ is evapotranspiration, $R_{0}$ is runoff, and $D_{\mathrm{r}}$ is drainage below the root zone. Initial SM, precipitation, and irrigation (if applied for an irrigated crop) are inputs to the model. Runoff is estimated by a method developed by the United States Soil Conservation Service (USSCS 1972). The role of varying permeability and infiltration rates due to changing soil surfaces were taken into consideration in determination of this runoff (McCuen 1982). In this model, drainage is calculated by an equation proposed by Campbell (1985).

The model separately calculates evaporation and transpiration and sums the two as ET. A modified version of Penman's (1948) combination method of potential ET estimation is used to derive evaporation $(E)$ and transpiration $(T)$. The Penman method is modified to account for wind as proposed by Kincaid \& Heerman (1974). Calculated evaporation is a function of poten- 
tial $E T$ and the number of days $(d)$ since the last precipitation event. This relationship can be expressed as follows:

$$
E=E T_{\mathrm{p}}(1 / d)^{1 / 2}
$$

where $E T_{\mathrm{p}}$ is the potential ET based on the modified Penman method. Calculated transpiration is a function of the crop and a phenology-specific crop-coefficient $\left(K_{\mathrm{c}}\right), E T_{\mathrm{p}}$, and a soil-water reduction factor $(f) . f$ restricts crop-water extraction as SM content approaches wilting point. Note that $f$ is a function of available SM and the water-holding capacity of the soil and changes in response to the ratio of available water to potential available water. Transpiration can be expressed as follows:

$$
T=f K_{\mathrm{c}}\left(E T_{\mathrm{p}}-E\right)
$$

The model was validated, and its performance was evaluated for various crops and sites (representing various soil conditions), and for 6 layers up to $1.8 \mathrm{~m}$ depth in Nebraska (Robinson \& Hubbard 1990). In addition, the SM model simulates water-holding capacity, current water stress, runoff, drainage, phenology, actual and potential ET (shown above), sensible heat flux, and net radiation, among others.

\section{APPLICATIONS OF THE R\&H MODEL AND RESULTS}

To determine the impacts of changes in agricultural land use on the components of near-surface hydrologic cycle in the Great Plains, 3 counties in Nebraska were selected-Saunders, York, and Red Willow. They are located along an east-to-west gradient of moist (Saunders) to dry (Red Willow) climatic conditions. Therefore, the potential response in more than 1 moisture regime under irrigation is estimated. One site from each of these counties was selected for the R\&H SM model run. These sites are Mead, Clay Center, and McCook, representing Saunders, York, and Red Willow County, respectively (Fig. 2). Automated weather stations at these sites provided input weather data for the R\&H model. These stations have been operating since 1981. Due to the incomplete weather data in 1981, the R\&H model is run from 1982 through 1998. Soil input data for these sites are also available for model application. Soils and climate data can be accessed from the High Plains Regional Climate Center. The soils data include bulk density, soil texture, wilting point, field capacity, and saturation point for each soil layer.

The SM model is applied for 3 different land uses, including grass, rainfed maize, and irrigated maize for each site. Grass represents the pre-agricultural natural vegetation. Rainfed and irrigated maize are 2 major a

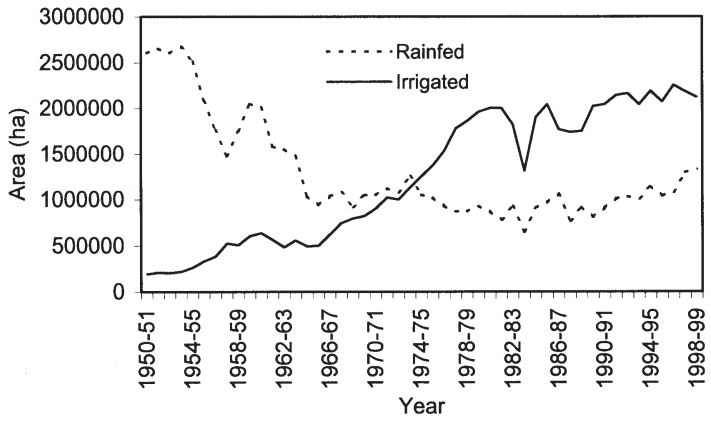

b

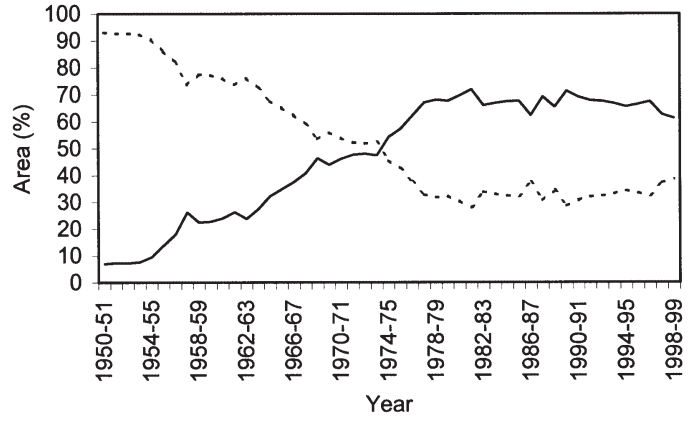

Fig. 1. Rainfed and irrigated corn farming in Nebraska (1950-1999)

agricultural land uses in Nebraska. Rainfed maize is relatively dominant in eastern Nebraska. In this area, sub-humid climate and moisture regimes along with the soils that have a high root zone water-holding capacity enable farmers to conduct dry land farming. Over the remainder of Nebraska between the late 1950s and the early 1960s, irrigated maize largely replaced rainfed maize.

In the R\&H model, May 5 was set as the beginning of the growing season for these crops. The phenological development of grass and maize cultivars grown under rainfed and irrigated conditions is controlled by a specific growth stage and accumulated growing degreedays. The specification of growing degree-days is important because growing season consumption and utilization of water by a crop is largely determined by the expansion of leaf area during phenological devel-

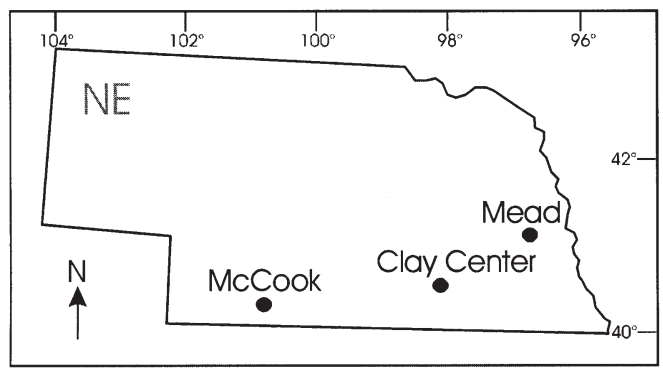

Fig. 2. Location of the study sites in Nebraska 

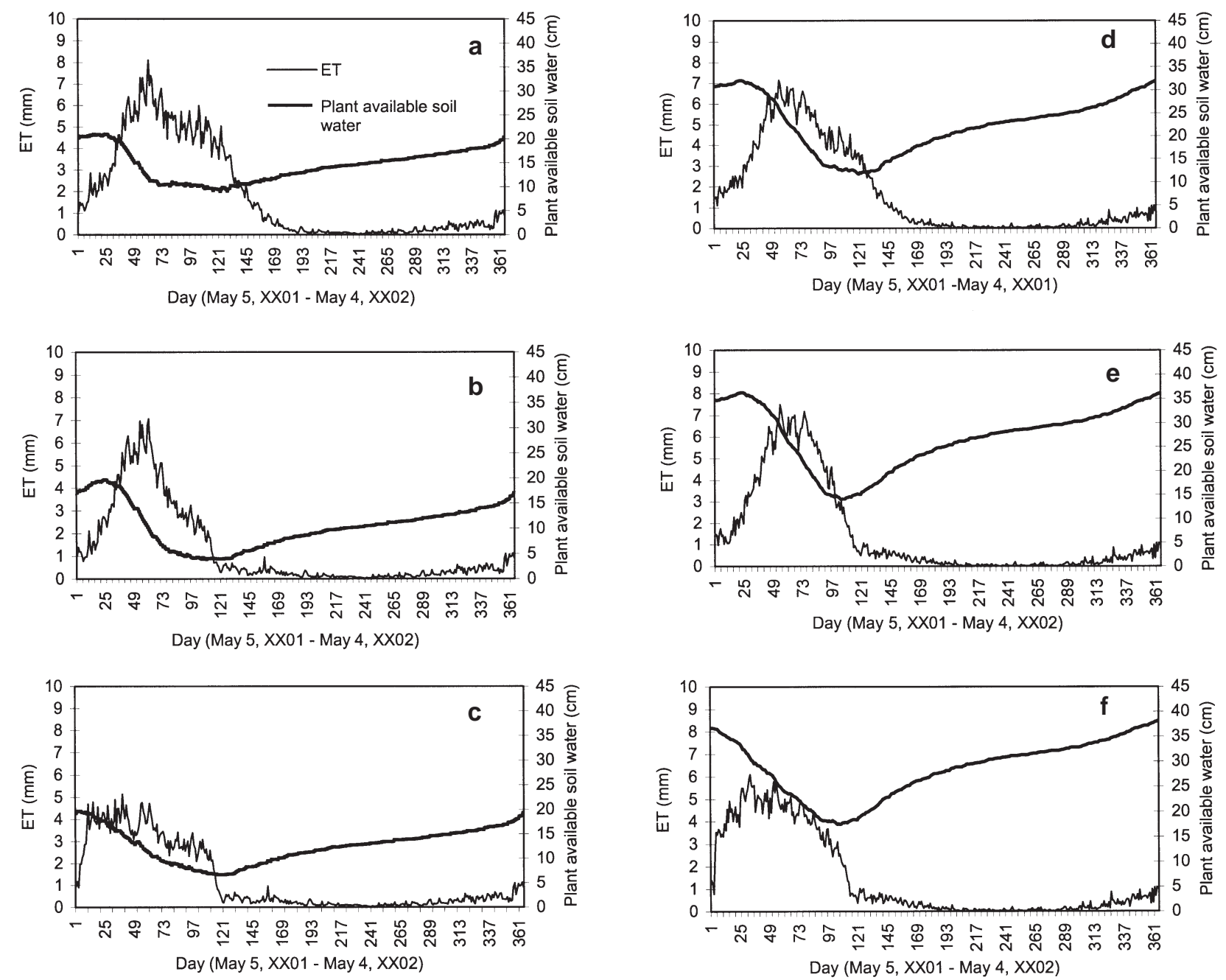

Fig. 3. Mean (1982-1999) daily evapotranspiration (ET) and plant available SM for 3 land uses at (a-c) McCook and (d-f) Mead, NE: $(\mathrm{a}, \mathrm{d})$ irrigated maize, (b,e) rainfed maize, and (c,f) grass. The first simulation starts on May 5, 1982, and ends on May 4, 1983. This process continues through 1998-1999. The soil moisture (SM) balance of a year carried over to the subsequent years. Therefore, the mean for the whole period is $365 \mathrm{~d}$ long and starts during Year 01 and completes during Year 02

opment. Hence, phenological development influences temporal changes in SM status, ET rates, and the energy balance.

The results from $\mathrm{R} \& \mathrm{H}$ SM model application at the drier McCook site clearly show that the amount of plant available SM throughout the growing season and year is higher for irrigated maize compared to rainfed maize and grass (Fig. 3a-c). Irrigation helped to maintain higher SM in the root zone. As expected, rainfed maize and grass are dependent on naturally available SM, and their extraction of SM reflects the underlying environment. Long-term model output data shows that water consumption by rainfed maize leads to the most rapid depletion of SM (Fig. 3b). By the end of the growing season, plant-available SM reduces, on average, to nearly 9, 4, and $7 \mathrm{~cm}$ for irrigated and rainfed maize and grass, respectively (Fig. $3 \mathrm{a}-\mathrm{c}$ ).
ET is largely controlled by atmospheric conditions (e.g. humidity, wind speed, solar radiation), SM availability, crop water requirements, and the plants' response to their surrounding environment. The R\&H model applications for McCook show that, on average, irrigated maize produces the highest daily rates of $\mathrm{ET}$, while grass produces the lowest (Fig. 3a-c). On the other hand, daily ET for rainfed grass increases and decreases more rapidly than irrigated and rainfed maize (Fig. 3c). Overall, increases and decreases of ET for both irrigated and rainfed maize are relatively gradual as the season progresses. It is also found from the model applications that due to the shorter growing season ET reduces significantly by the 121st day, on average, for rainfed maize and grass (Fig. 3a,b). Additionally, high daily rates in irrigated maize result in significantly higher annual totals of ET compared to 
rainfed maize and grass (Fig. 4a). On average, the annual total ET for irrigated and rainfed maize and grass is 694,462 , and $449 \mathrm{~mm}$, respectively. Therefore, ET under rainfed maize and grass, compared to irrigated maize, is 34 and $36 \%$ less, respectively.

To further investigate the impacts of land-use change on ET, area total ET (AET) [in $\mathrm{m}^{3}(\mathrm{ET} \times$ area)] from 1950 through 1999 is calculated for Red Willow county. It is noted above that ET could not be estimated prior to 1982 because of unavailability of input data for the R\&H SM model. However, to estimate the impacts of land-use change on AET from 1950 through 1981, the average annual total ET is used. The mean ET estimate is calculated from the model runs (19821998). The use of the mean value of ET in the AET computation reduces interannual variability. On the other hand, it provides reasonable AET estimates for further comparison. Fig. 5a demonstrates the rapid expansion of irrigated maize cultivation since 1950 in Red Willow County. The area under irrigated maize increased nearly $1200 \%$ between 1950 and 1975, and rainfed maize farming decreased nearly $1500 \%$. AET is estimated for irrigated and rainfed maize and grass for Red Willow county (Fig. 5b). Estimates for grass permitted us to determine AET for an unaltered landscape prior to the recent agricultural expansion. Moreover, it provides a benchmark against which we can measure changes since the 1950s. This study estimates that up to 50 million $\mathrm{m}^{3}$ of excess water is pumped into the atmosphere in any given year due to maize farming (rainfed + irrigated) in Red Willow County alone (Fig. 5b). During a number of years since the mid1970s, the difference in AET between irrigated maize and rainfed maize and between irrigated maize and grass was greater than 100 million $\mathrm{m}^{3} \mathrm{yr}^{-1}$ for Red Willow County. In other words, nearly all additional water evapotranspired into the atmosphere originated from irrigated maize fields (Fig. 5b). It is important to note that this additional volume of water evapotranspired during the growing season. Thus, it occurs during a particular 5 mo (May-September) period.

The R\&H model simulations for Clay Center calculated a temporal pattern in mean daily ET and plantavailable SM similar to that at McCook. The mean daily plant-available SM is highest for irrigated maize and lowest for rainfed maize. Compared to McCook, Clay Center has higher amounts of plant-available SM because of the texture of local soils. For example, the lowest mean daily plant-available SM for irrigated and rainfed maize and grass is approximately 11, 9, and $11 \mathrm{~cm}$, respectively. At Clay Center, average annual total ET for irrigated and rainfed maize and grass is 683, 521, and $503 \mathrm{~mm}$, respectively (Fig. 4b). Thus, ET from irrigated fields is $27 \%$ higher compared to grass and $24 \%$ higher compared to rainfed maize covered
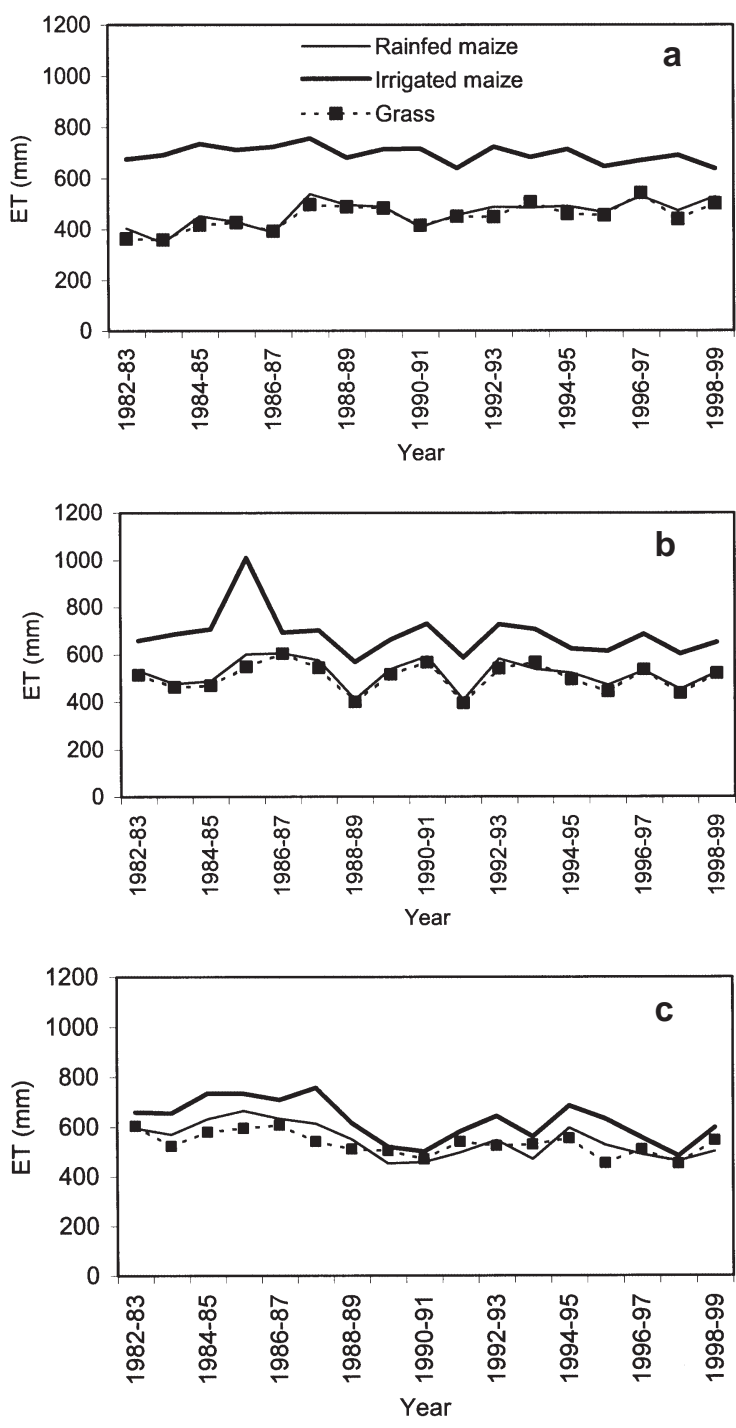

Fig. 4. Annual total ET for the 3 land uses at: (a) McCook, (b) Clay Center, (c) Mead

lands. Dry conditions resulted in slightly higher average annual total ET for irrigated maize at McCook. Higher precipitation at Clay Center allowed rainfed maize and grass to evapotranspire at higher rates.

Land-use data show that between 1950 and 1999 the area under irrigated maize increased from 3500 to 80000 ha $(2300 \%$ increase) in York County (Fig. 5c). At the same time the area under rainfed maize farming declined rapidly. AET also reflects this rapid change in land use (Fig. 5d). Model output showed that irrigated maize, compared to grass, contributed up to 100 million $\mathrm{m}^{3}$ of additional water during a growing season in York County.

Application of the R\&H model at the Mead site demonstrates a pattern in the mean daily distribution of ET and plant-available SM that is similar to other 

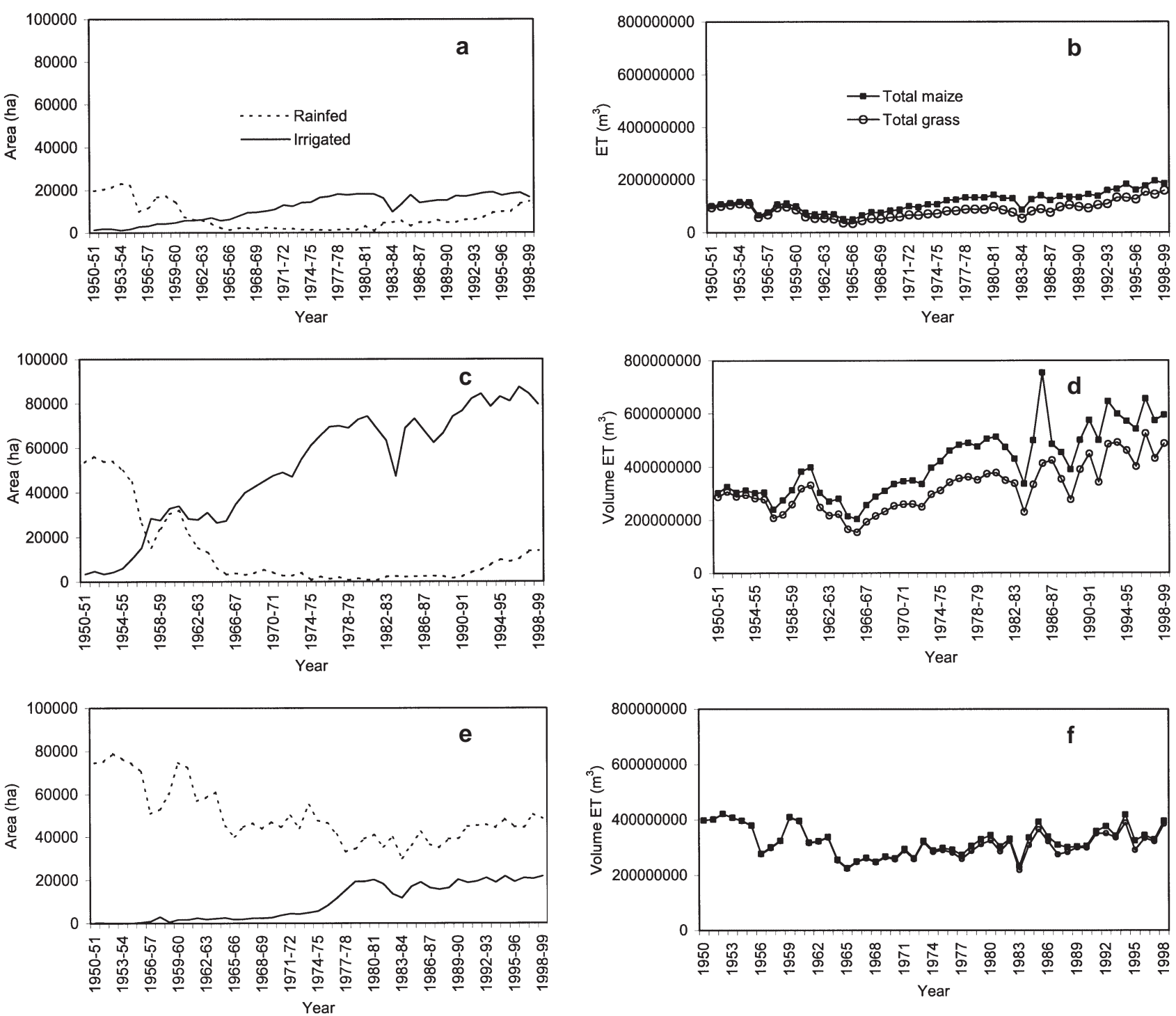

Fig. 5. $(\mathrm{a}, \mathrm{c}, \mathrm{e})$ Land-use area change and $(\mathrm{b}, \mathrm{d}, \mathrm{f})$ area total ET (AET) estimates for various land uses: $(\mathrm{a}, \mathrm{b})$ Red Willow County, $(\mathrm{c}, \mathrm{d})$ York County and $(\mathrm{e}, \mathrm{f})$ Saunders County, NE. Total maize: sum of annual total ET from irrigated and rainfed maize; Total grass: assumes landscape was unaltered and covered with natural grass as it was before human settlement

sites (Fig. 3d-f). The amount of daily mean plantavailable moisture stored in the soil at Mead is higher for the 3 land uses at any time compared to McCook and Clay Center. This study found that the lowest mean daily plant-available SM for irrigated and rainfed maize and grass is 12,14 , and $17 \mathrm{~cm}$, respectively. Note that the lowest mean daily plant-available SM is found under irrigated maize, not for rainfed maize. The primary reason is the fact that the growing season for irrigated maize is longer and plant-available SM quantity is higher due to the moist sub-humid environment. This led to reduced demand for irrigation water and greater use of available SM by maize plants, which, in turn, resulted in lower plant-available SM as irrigated maize plants had a considerably longer time to 'mine' the water.

At Mead, the annual total ET from irrigated maize is generally higher compared to rainfed maize and grass for any given year (Fig. 4c). The average annual total ET for irrigated and rainfed maize and grass is 625 , 544 , and $531 \mathrm{~mm}$, respectively. In other words, on average, ET for irrigated maize is 16 and $13 \%$ higher compared to grass and rainfed maize, respectively. There is a clear trend in decreasing ET for irrigated maize and increasing ET for rainfed maize and grass as the model applications progressed from drier McCook to relatively moist Mead. For irrigated maize, higher atmospheric demand and the subsequent supply of water in 
western Nebraska resulted in higher annual total ET in McCook. On the other hand, despite the higher atmospheric demand, the relatively restricted supply of moisture for rainfed maize and grass resulted in lower annual total ET in McCook.

As in the previous cases, irrigated maize farming increased rapidly in Saunders County while rainfed farming decreased (Fig. 5e). Nevertheless, rainfed maize is still the dominant land use in Saunders County. As a result, a large portion of annual AET originates from rainfed maize farming areas of this County. Changes in land use from grass to maize farming (rainfed and irrigated) have resulted in increased amounts of evapotranspired water in the atmosphere (Fig. 5f). In Saunders County, compared to grass, this additional evapotranspired water is up to 50 million $\mathrm{m}^{3}$.

\section{CONCLUDING REMARKS}

This paper demonstrates the impacts of land-use change on near-surface hydrologic cycle components, including SM and ET. The study was conducted for the tall grass-short grass transition of the North American Great Plains. Previous work demonstrated that modification of land use influences regional climate, mesoscale circulation, and near-surface temperature (e.g. Segal et al. 1988, Yan \& Anthes 1988, Pielke \& Zeng 1989, Stohlgren et al. 1998, and Pielke et al. 1999). Thus, there was a lack of understanding regarding SM in the root zone of the modified landscape. In addition, the response of SM in the root zone of specific vegetation covers over changing landscapes and contrasting hydroclimatic conditions was not explored in the past. The SM and ET time series used in this study are longer than the previous studies. The longer time series provide a better understanding of the impacts of land-use change on near-surface hydrologic cycle components. The R\&H model (Robinson \& Hubbard 1990) applications at 3 Nebraska sites representing dry to moist hydroclimatic conditions found that irrigated maize farming is evapotranspiring a large amount of additional water to the atmosphere compared to natural grass in an unaltered landscape. In McCook, Nebraska, annual total ET for irrigated and rainfed maize is 36 and $2 \%$ higher than grass, respectively, and thus serves as a source of moisture in a drier region. The land use also influenced the SM balance. Compared to grassland use, irrigated and rainfed maize farming elevated and lowered plant-available SM by adding and mining water, respectively.

We believe the results of this study have significance in formulating a strategy for global change and global climate change studies. It is shown that land-use changes are modifying near-surface hydrologic con- ditions. Therefore, relationships between land-use change and various components of the environment, including soil moisture and evapotranspiration, need to be included as an important research item within the general framework and specific objectives of globalchange studies. This incorporation will improve our understanding of near-surface climatic records and will enable us to identify anthropogenic imprints on natural variations of the hydrologic cycle. The extensive land-use changes recorded in the Great Plains can also be found in other parts of the world. Studies should be designed carefully to identify land-use changes and to estimate their impacts on near-surface atmospheric and hydrologic variables. Only then will we understand the contribution of land-use modification on local and regional climate change during the last century.

Previously, it was hypothesized that recent changes in average global tropospheric temperature are a consequence of increasing sea-surface temperature (SST) (Morrissey \& Graham 1996). It has also been proposed that the increase in SST resulted in an enhanced hydrological cycle (Morrissey \& Graham 1996). In addition, scientists are struggling to explain the role of greenhouse gases in global temperature variations (IPCC 1996, Santer et al. 1996, Tett et al. 1999). In the context of these findings (Morrissey \& Graham 1996, Santer et al. 1996), the present study reveals that further investigation is an absolute necessity to determine the impacts of land-use changes in recent climatic records.

Acknowledgements. The authors would like to thank 3 reviewers and the editor for their valuable suggestions. Thanks also go to Drs Daniel T. Walters and William J. Waltman for their comments during the preparation of this manuscript. Technical assistance provided by Sebastien Korner in preparation of the map is much appreciated. This paper has a Journal Series No. 13314, University of Nebraska Agricultural Research Division, Lincoln, NE.

\section{LITERATURE CITED}

Balling RC Jr (1988) The climatic impact of a Sonoran vegetation discontinuity. Clim Change 13:99-109

Balling RC Jr, Klopatek JM, Hildebrandt ML, Moritz CK, Watts CJ (1998) Impacts of land degradation on historical temperature records from the Sonoran desert. Clim Change 40:669-681

Bonan GB (1997) Effects of land use on the climate of the United States. Clim Change 37:449-486

Bonan GB (1999) Frost followed the plow: impacts of deforestation on the climate of the United States. Ecol Appl 9: $1305-1315$

Bonan GB (2001) Observational evidence for reduction of daily maximum temperature by croplands in the Midwest United States. J Clim 14:2430-2442

Bounoua L, Collatz GJ, Los SO, Sellers PJ, Dazlich DA, 
Tucker CJ, Randall DA (2000) Sensitivity of climate to changes in NDVI. J Clim 13:2277-2292

Campbell GS (1985) Soil physics with basic. Elsevier, New York

Chase TN, Pielke RA Sr, Kittel TGF, Baron JS, Stohlgren TJ (1999) Potential impacts on Colorado Rocky Mountain weather due to land use changes on the adjacent Great Plains. J Geophys Res 104:16673-16690

Fitzjarrald DR, Acevedo O, Moore KE (2001) Climatic consequences of leaf presence in the eastern United States. J Clim 14:598-614

Hoffman W, Jackson RB (2000) Vegetation-climate feedbacks in the conversion of tropical savanna to grassland. J Clim 13:1593-1602

Houghton RA, Hackler JL, Lawrence KT (1999) The U. S. carbon budget: contribution from land-use change. Science 285:574-578

Intergovernmental Panel on Climate Change (IPCC) (1996) Climate change. In: Houghton JT, Filho LGM, Callender BA, Harris N, Kattenberg A, Maskell K (eds) Cambridge University Press, Cambridge, UK

Kincaid DC, Heerman DF (1974) Scheduling irrigations using programmable calculator. USDA-ARS-NC-12. US Government Printing Office, Washington, DC

Mahmood R, Hubbard KG, Hou Q (2001) Soil moisture monitoring and modeling in the Great Plains. In: Hubbard KG, Sivakumar MVK (eds) Automated weather stations for applications in agriculture and water resources management: current use and future perspective. High Plains Regional Climate Center, Lincoln, NE, and World Meteorological Organization, Geneva, p 163-171

McCuen RH (1982) A guide to hydrologic analysis using SCS methods. Prentice-Hall, Englewood Cliffs, NJ

Milly PCD, Dunne KA (1994) Sensitivity of the global water cycle to the water-holding capacity of land. J Clim 7 : 506-526

Morrissey ML, Graham NE (1996) Recent trends in rain gauge precipitation measurements from the tropical Pacific: evidence for enhanced hydrologic cycle. Bull Am Meteorol Soc 77:1207-1219

Penman HL (1948) Natural evapotranspiration from open water, bare soil and grass. Proc R Soc Lond A 193:120-145

Pielke RA, Zeng X (1989) Influence on severe storm development of irrigated land. Natl Weather Dig 14:16-17

Pielke RA Sr, Walko RL, Steyaert LT, Vidale PA, Liston GE, Lyons WA, Chase TN (1999) The influence of anthro-

Editorial responsibility: Robert Davis,

Charlottesville, Virginia, USA pogenic landscape changes on weather in South Florida. Mon Weather Rev 127:1663-1673

Ramankutty N, Foley JA (1999) Estimating historical changes in global land cover: croplands from 1700 to 1992. Global Biogeochem Cycles 13:997-1027

Robinson JM, Hubbard KG (1990) Soil water assessment model for several crops in the high plains. Agron J 82: $1141-1148$

Santer BD, Taylor KE, Wigley TML, Johns TC, and 9 others (1996) A search for human influences on the thermal structure of the atmosphere. Nature 382:39-46

Schimel J (1999) Rice, microbes, and methane. Nature 403: 375-377

Segal M, Avissar R, McCumber MC, Pielke RA (1988) Evaluation of vegetation effects on the generation and modification of mesoscale circulations. J Atmos Sci 45:2268-2292

Segal M, Schreiber W, Kallos G, Pielke RA, Garatt JR, Weaver J, Rodi A, Wilson J (1989) The impact of crop areas in northeast Colorado on midsummer mesoscale thermal circulations. Mon Weather Rev 117:809-825

Shukla J, Norbe C, Sellers P (1990) Amazon deforestation and climate change. Science 247:1322-1325

Sitzman LE (1996) Nebraska crops and weather. Agricultural Statistics Service, Lincoln, NE

Stohlgren TJ, Chase TN, Pielke RA Sr, Kittel TGF, Baron J (1998) Evidence that local land use practices influence regional climate, vegetation, and stream flow patterns in adjacent natural areas. Glob Change Biol 4:495-504

Tett SFB, Stott PA, Allen MR, Ingram WJ, Mitchell JFB (1999) Causes of twentieth century temperature change near the Earth's surface. Nature 399:569-572

US Soil Conservation Service (1972) National engineering handbook. USDA, Washington, DC

Wetzel PI (1989) A simple parcel method for prediction of cumulus onset and area-averaged cloud amount over heterogeneous land surfaces. J Appl Meteorol 29:519-523

Williams JH, Murfield D (1977) Agricultural atlas of Nebraska. University of Nebraska Press, Lincoln, NE

Yan H, Anthes RA (1988) The effect of variations in surface moisture on mesoscale circulations. Mon Weather Rev 117:192-208

Zeng N, Dickinson RE, Zeng X (1996) Climatic impact of Amazon deforestation-a mechanistic study. J Clim 9: 859-883

Zhang H, Henderson-Sellers A (1996) Impacts of tropical deforestation. J Clim 9:1497

Submitted: April 3, 2001; Accepted: October 8, 2001

Proofs received from author(s): April 8, 2002 